\title{
ČESKÁ VOJENSKÁ PŘíRUČKA Z ROKU 1618
}

\author{
Klára Andresová (Praha)
}

\begin{abstract}
A Czech Military Handbook from 1618
In the early modern period, only a few military handbooks were printed in the Czech language in the Kingdom of Bohemia. The first of them was a translation of Kriegs Discurs written by Lazarus von Schwendi, which was published by Daniel Carolides in Prague in 1618 as Discurs o běhu válečném [A Discourse on the Course of War]. The book was translated from German by Bartoloměj Havlík of Varvažov and edited by his son Jan Havlík of Varvažov. It was published only six months after the beginning of the Bohemian Revolt, which started the Thirty Years' War. It is possible that this handbook was printed because its originators wanted to support the Bohemian Revolt. The book was dedicated to one of the main figures of the revolt - Albrecht Jan Smiřický, who however died only a few days after the publication of the title. Discurs o běhu válečném presented military thoughts from the 1550s together with some later ideas from the 1570s. The publication discussed the military organisation, various military ranks and offices and the obligations of soldiers. The book has been published in Czech only once, but there are at least four editions in German.
\end{abstract}

Key words: military handbooks - military organisation -Thirty Years' War - Czech printing -17 th century

V listopadu 1618, necelého půl roku po třetí pražské defenestraci a vypuknutí českého stavovského povstání, vyšla tiskem pravděpodobně první vojenská příručka $\mathrm{v}$ češtině. Drobná knížka nazvaná Discurs o běhu válečném a ouradech vojenských ${ }^{1}$ byla $\mathrm{v}$ rámci svého žánru skutečně jedinečná a po dlouhá léta neměla v Českém království obdoby. Zatímco se v našich zemích vojenské příručky dosud nevydávaly, ${ }^{2}$ za hranicemi byla situace jiná a tisk tohoto žánru byl v některých státech střední Evropy již poměrně běžný. Zhruba od poloviny 16 . století vycházely německé vojenské příručky v relativně hojném množství a ani polské vojenské spisy nebyly zcela výjimečné. ${ }^{3}$

S jazykově českými vojenskými př́ručkami, které vyšly tiskem, se až do 18. století prakticky nesetkáme, a teprve v 19. století začalo množství těchto knih narůstat. ${ }^{4}$ Za této situace představovala publikace, která je předmětem tohoto př́spěvku, ve své době skutečný unikát. Bylo tomu tak ovšem pouze v rámci tištěné literatury, protože vojenské rukopisy v českém jazyce se po našich zemích v 16. a 17. století šírily. Zmínit můžeme např. Instrukci vojanskou Zikmunda Chotka z Chotkova z roku $1593,{ }^{5}$ nebo rukopisné překlady cizích děl do češtiny. ${ }^{6}$ Většina vojenských příruček, které bylo možné nalézt $\mathrm{v}$ tehdejších českých a moravských knihovnách, však byla cizojazyčná.

Jedním z důvodů, proč čeští a moravští zájemci o vojenské teoretické spisy nevyžadovali více příslušných textů $\mathrm{v}$ českém jazyce, byla dostatečná znalost němčiny v dané sociální skupině. ${ }^{7}$ Čtenáři vojenských příruček byli převážně šlechtici a zámožnější měšt'ané. ${ }^{8} \mathrm{U}$ nich bylo možné předpokládat nejen znalost němčiny, ale i dalších jazyků, v nichž

\footnotetext{
1 SCHWENDI 1618. Přepis názvů děl a citovaných pasáží v hlavním textu byl proveden na základě doporučení publikace ŠŤOVÍČEK 2002.

2 Ve zkoumaném období do roku 1650 nebyla v českých zemích tiskem vydána žádná jiná vojenská př́ručka, která by se dochovala do dnešních dnů, a to v českém ani v jiném jazyce. (Srov. databáze Knihopis a Bibliografie cizojazyčných bohemikálních tisků https://knihoveda.lib.cas.cz/.)

K vojenským příručkám v letech 1550-1650 ve střední Evropě více viz ANDRESOVÁ 2018.

4 Srov. JUNGMANN 1849, s. 474

5 Později vydáno: CHOTEK Z CHOTKOVA 1895, s. 415-442.

6 Právě z takového překladu později vzešlo i vydání knihy Discurs o Běhu Wálečném.

7 Němčina byla v Českých zemích poměrně běžně užívaným jazykem, a proto na našem území tehdy vznikaly v němčině i vojenské rukopisy - např. Kriegsdiscurs über der hochlöblichen Cron Böhmen Landtdefension Jindřicha Michala Hýzrla z Chodů. Kritická edice př́slušného díla a jeho překlad do češtiny: OPAVOVÁ 2013, s. 84-168.

${ }^{8}$ K vzdělávání př́slušných sociálních vrstev v období renesance v Českých zemích viz HOLÝ 2010. Konkrétně ke studiu cizích jazyků pak především na s. 90-99.
} 
byly tištěny vojenské prríručky dodnes uložené v některých českých knihovnách. ${ }^{9}$

\section{České vojenské příručky raného novověku vydané tiskem}

Discurs o běhu válečném je nejstarší dochovanou vojenskou příručkou vytištěnou v českém jazyce. Je však možné, že existovala ještě starší publikace tohoto žánru, která se dodnes nedochovala. Jungmannova Historie literatury české $e^{10}$ i Knihopis českých a slovenských tisků zmiňují publikaci osmerkového formátu Knižka o polním hejtmanu a jiných správcich vojenských. ${ }^{11}$ (Zda se jednalo přímo o název, či o charakteristiku obsahu knihy, nemůžeme s jistotou říci.) Autorem spisu měl být Jan Achilles (asi 1545 - po 1617), evangelický kazatel a humanistický spisovatel. ${ }^{12}$ Vzhledem $\mathrm{k}$ autorově konfesijní příslušnosti byla publikace zařazena do soupisu Index Bohemicorum Librorum Prohibitorum z roku 1770, můžeme tedy předpokládat, že v době vydání Indexu nějaké kopie př́íslušného spisu existovaly. ${ }^{13}$

Do dnešních dnů se však žádný exemplář zmíněné publikace nedochoval, nebo se o něm alespoň neví. Není proto jisté, do jakého žánru daná kniha ve skutečnosti náležela. Ačkoliv její (předpokládaný) název naznačuje, že by se o vojenskou prríručku jednat mohlo, s ohledem na další autorovu publikační aktivitu vyvstávají pochybnosti. Tematika všech dalších spisů Jana Achillea, které dnes známe, je náboženská - ve většině př́padů se jedná o kázání. Je tedy možné, že Knížka o polním hejtmanu patřila do skupiny náboženských příruček, s pomocí nichž se měli vojáci vzdělat v oblasti mravného a zbožného chování v situacích, které je při vojenské službě mohly potkat. Jedním z dochovaných př́kladů publikace tohoto typu je Kázání krátké, ku potěšení a napomenutí pobožným vojákům od Jiřího Bartolomea $\mathrm{z}$ roku $1619 .^{14}$

Přeskočíme-li nyní ve chronologickém výčtu Discurs o běhu válečném, na který se detailněji zaměříme později, nalezneme další vojenské příručky vytištěné v českém jazyce až v 18. století. Z roku 1733 pochází vojenský předpis pro dragounský pluk hraběte Ludwiga Andrease von Khewenhüllera (1683-1744), který byl téhož roku povýšen do hodnosti polního podmaršálka. ${ }^{15} \mathrm{Z}$ roku 1798 je dochován jediný fragment armádních předpisů, které byly v pozdějších letech bibliografy pracovně nazvané Článkové vojenští pro c. k. armádu. ${ }^{16}$

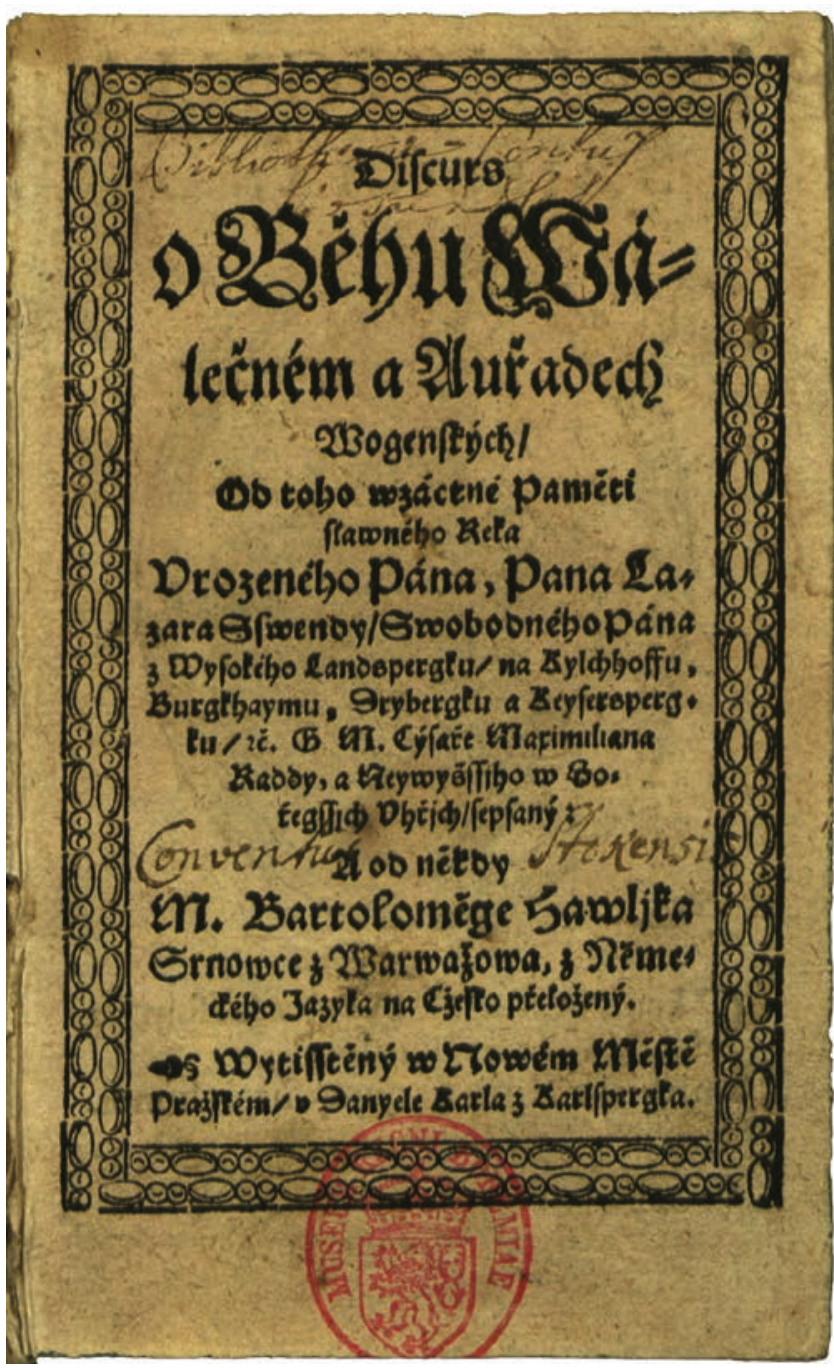

Obr. 1. Titulní list českého vydání Discursu o běhu válečném. Praha, Knihovna Národního muzea, oddělení rukopisů a starých tisků, sign. 30 D 7. Foto: KNM.

O rok mladší je potom spisek Přednosti stavu vojenského od Jana Hoška, ${ }^{17}$ který se typově liší od předešle uvedených titulů. Nejedná se již o naučnou publikaci pro vzdělané důstojníky, jako tomu bylo $\mathrm{v}$ prrípadě vojenských příruček 16. a 17. století - mj. i Discursu o běhu válečném. Není to ani soubor závazných předpisů, jaké jsme představili v rámci obou předchozích českých vojenských príruček z 18 . století. Přednosti stavu vojenského jsou naučným textem určeným

\footnotetext{
9 Za příklad může sloužit Knihovna Vojenského historického ústavu Praha, která ve svém tzv. starém fondu drží publikace z řady zaniklých šlechtických a posádkových knihoven, které se nacházely na území dnešní České republiky. (K historii knihovny více JANOVSKÝ 1993.) Nalezneme v ní celkem 221 různých vydání vojenských př́ruček z let 1550-1650. Z nich je 91 tištěno v němčině, 62 v italštině, 38 ve francouzštině, $18 \mathrm{v}$ latině, 9 ve španělštině a 3 v holandštině. (Analýza byla provedena na základě katalogu knihovny: https://vhupraha.kpsys.cz/\#!! [cit 8. 7. 2019].) Za patrně nejvýznamnější dobové vojenské autory, jejichž díla lze dodnes dohledat v českých knihovnách, lze označit Leonhardta Fronsbergera (1520-1575), Giorgia Bastu (1550-1612), Johanna Jacobiho von Wallhausena (1580-1627) a již představeného Lazara von Schwendiho. (Srov. kromě výše uvedeného katalogu Knihovny VHÚ také Souborný katalog ČR http://www.caslin.cz/ [cit. 20. 2. 2020] nebo např. katalog Knihovny Královské kanonie premonstrátů https://tritius.strahovskyklaster.cz/ [cit. 20. 2. 2020].) O těchto autorech a jejich díle více např. ANDRESOVÁ 2019.

${ }^{10}$ JUNGMANN 1849, s. 175.

${ }^{11}$ ACHILLES 1595.

${ }^{12} \mathrm{~K}$ němu více viz Biografický slovnik 2004, s. 47

${ }^{13}$ KONIÁŠ 1770 , s. 8. Z tohoto soupisu byl ostatně také přejat její záznam do Jungmannovy Historie a později do Knihopisu.

${ }^{14}$ BARTOLOMEUS [1619?]

${ }^{15}$ KHEWENHÜLLER 1733 .

${ }^{16}$ ZLOBICKÝ1798. Název publikace není dobový, jelikož v roce 1798 dosud neexistovaly „c. k.“ instituce, tedy ani „c. k. armáda“

${ }^{17}$ HOŠEK 1799.
} 


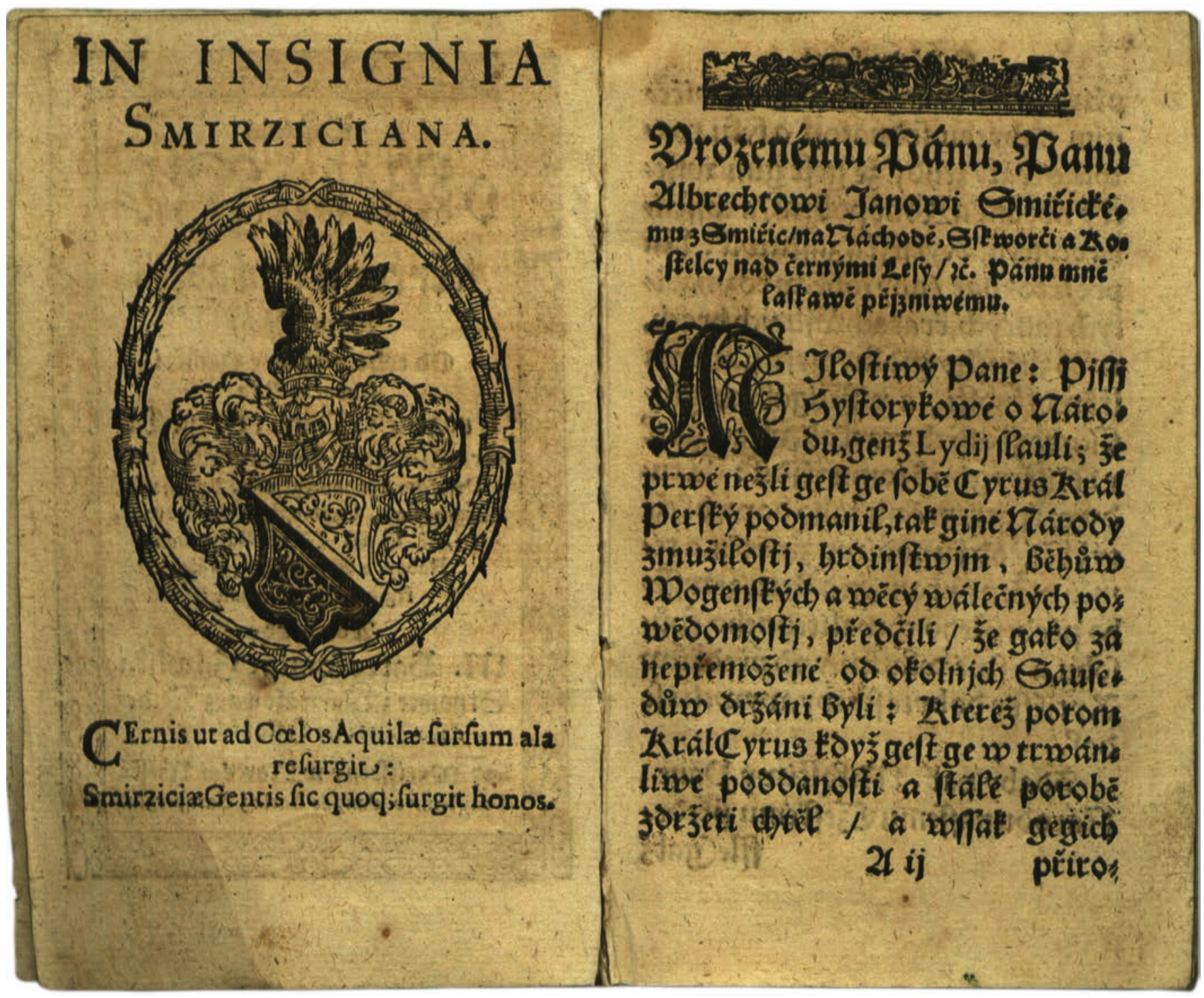

Obr. 2. Dedikace Albrechtu Janovi Smiřickému. Praha, Knihovna Národního muzea, oddělení rukopisů a starých tisků, sign. 30 D 7. Foto: KNM.

prostým vojákům, kteří se na jeho stránkách měli prostřednictvím otázek a odpovědí seznámit se všemi náležitostmi správného života a služby vojáka př́slušné armády. Tento typ vojenských př́ruček byl obvyklý i v 19. století.

Tímto krátkým výčtem jsme shrnuli tři hlavní typy vojenských prŕruček raného novověku, ale také veškeré vojenské příručky, které vyšly tiskem v českém jazyce mezi 16. a 18. stoletím, o nichž se nám dodnes dochovaly nějaké informace.

\section{Discurs o běhu válečném a ouřadech vojenských}

Představovaná první česká vojenská příručka ovšem nebyla původním českým dílem, ale překladem poměrně známé německé publikace Lazara von Schwendiho (1522-1583), která byla vydána ve svém originálním jazyce již třikrát pod názvem Kriegs Discurs. ${ }^{18}$ Lazarus von Schwendi byl významným císařským diplomatem a vojevůdcem, který se zúčastnil šmalkaldské války (1546-1547) a později se proslavil jako generál bojující v Uhrách proti Turkům. ${ }^{19}$ Schwendiho dílo bylo ovlivněno jeho válečnými zkušenostmi, a vyjadřovalo se proto $\mathrm{v}$ nemalé míře $\mathrm{k}$ tureckému nebezpečí a turecké problematice. Kriegs Discurs byl poprvé vydán roku 1593, sepsán byl však už mezi lety 1571 a $1575 .{ }^{20}$ Historie spisu je ovšem delší - větší část tohoto díla vznikla přepracováním staršího anonymního rukopisu Forma und Ordnung eines Kriegsbuches z 50. let 16. století. $^{21}$ Český Discurs o běhu válečném z roku 1618 tak

\footnotetext{
${ }^{18}$ Poprvé se tak stalo roku 1593. Poté bylo dílo znovu vydáno v letech 1594 a 1605. Další, upravené vydání vyšlo roku 1676. (Srov. databáze VD16 www.vd16.de a VD17 www.vd17.de.)

${ }^{19}$ K jeho osobě více viz např. KÖNIG 1934; nověji pak NICKLAS 1995.

${ }^{20}$ KÖNIG 1934, s. 88. Rukopis daného díla je uložen v Rakouské národní knihovně: SCHWENDI, Lazarus von. Ein kurzer Begriff von den Kriegsämptern. Österreichischen Nationalbibliothek, sign. Cod. 10893 HAN MAG.

${ }^{21}$ Srov. KÖNIG 1934, s. 88; PICKOVÁ 1965, s. 790; JÄHNS 1890, s. 534.
} 


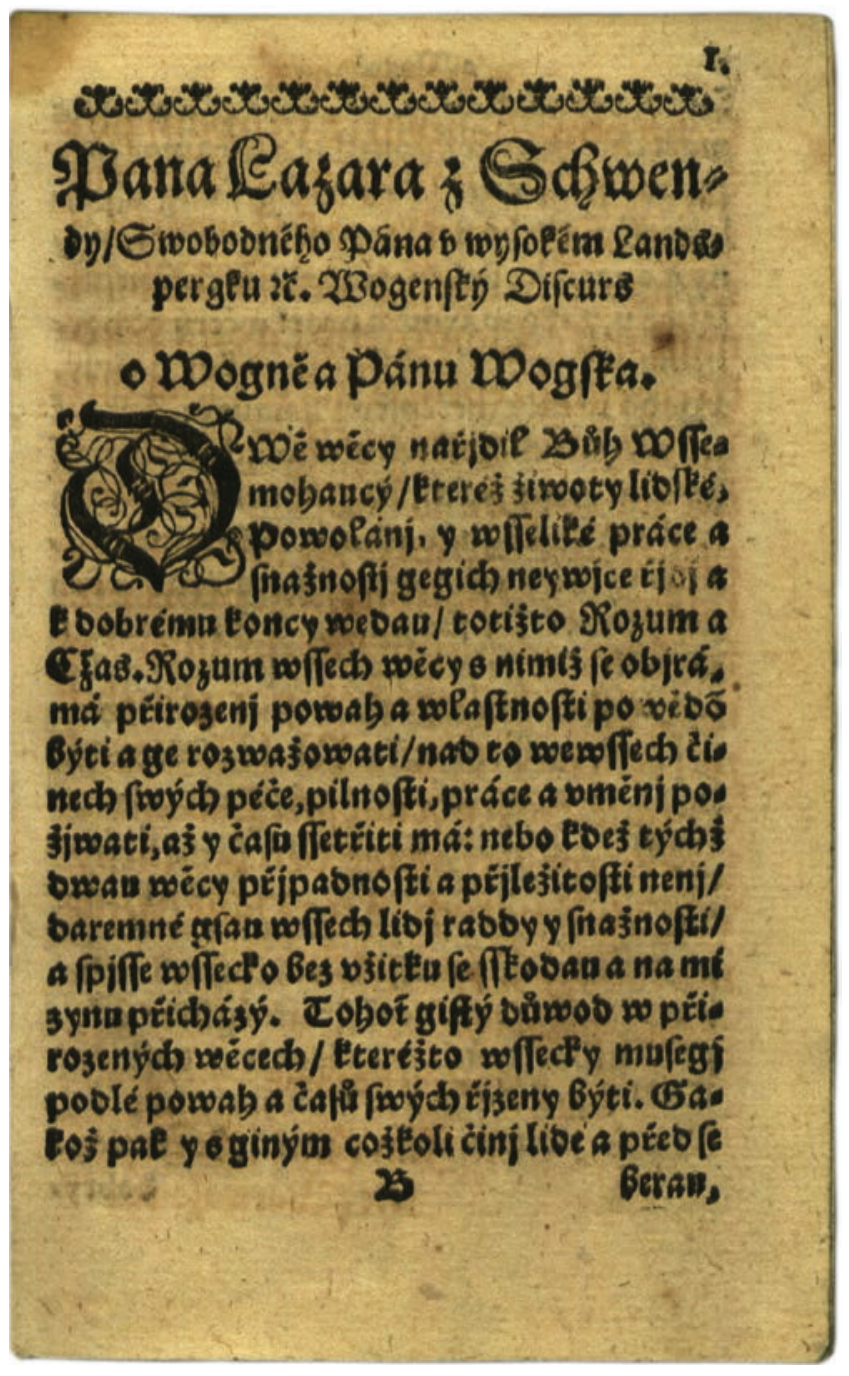

Obr. 3. Začátek hlavního textu publikace - první kapitola O vojně a pánu vojska. Praha, Knihovna Národního muzea, oddělení rukopisů a starých tisků, sign. 30 D 7. Foto: KNM.

obsahoval především informace o vojenství staré šedesát let, které byly doplněny více než čtyřicet let starými poznatky o válkách proti Turkům. Obsahově tedy hlavní text knihy žádným způsobem nereagoval na české stavovské povstání, které právě probíhalo a mělo vyústit v třicetiletou válku (1618-1648).

Zatímco Schwendi ve svém díle aktualizoval některé informace ze zdrojového rukopisu Forma und Ordnung, při překladu publikace do češtiny žádné nové vojenské poznatky doplněny nebyly. Porovnáme-li Discurs o běhu válečném s německým originálem, zjistíme, že česká varianta skutečně odpovídá původnímu Schwendiho dílu. Překladatelem daného německého spisu do češtiny byl humanistický učenec a spisovatel Bartoloměj Havlík z Varvažova (1552-1609). ${ }^{22}$
Havlík se však o vydání svého překladu nezasloužil. Zemřel již roku 1609 a rukopis, který vytvořil, měl sloužit patrně pouze pro jeho osobní potřebu. To ostatně vyplývá i z předmluvy Discursu o běhu válečném, kterou sepsal Bartolomějův syn Jan Havlík z Varvažova (1598 - před 1649). Jan byl stejně jako jeho otec humanistickým učencem a stal se editorem představované publikace. ${ }^{23} \mathrm{~V}$ její předmluvě uvádí: „Majíce mezi kněhami mými toho slavného rytíře pána, pana Lazara z Šwendy Discurs o boji a regimentu vojenském, někdy od dobré paměti $\mathrm{M}$ [istra]. Bartoloměje Havlíka z Varvažova, pana otce mého milého, z německého jazyka do českého přeložený (...).“ Jan Havlík zde zjevně mluví o rukopisném překladu vytvořeném jeho otcem, který po otci také zdědil a zařadil do své knihovny.

\section{Předmluva a dedikace knihy}

Předmluva publikace je datovaná ,ve čtvrtek den památný všech svatých“ - tedy prvního listopadu - roku 1618. Mluvíme zde tudíž o vojenské příručce, která byla vydána v Praze skoro půl roku poté, co na tomtéž místě propuklo stavovského povstání. V dané době již obě znepřátelené strany několik měsíců zbrojily a najímaly vojáky. K prvním šarvátkám došlo v létě 1618, první polní bitva proběhla v polovině zárí u Čáslavi. ${ }^{24}$ Dalo by se tedy očekávat, že bude na tento konflikt reagovat alespoň předmluva právě vycházející vojenské publikace. Musíme však konstatovat, že se tak nestalo, či že se tak nestalo explicitně.

V předmluvě se setkáváme s dobovým vlastenectvím. Pisatelova konfesijní př́slušnost není v textu výslovně vyjádřena, ač se na ni dá usuzovat ze sympatií vưči zmiňovaným osobám. O tehdejším politickém dění není řečeno nic konkrétního, autor textu pouze na několika místech zmiňuje ,věk tento zlý“ ${ }^{25}$ mluví o ,těchto nynějších těžkých časích“26 a doufá $\mathrm{v}$ pomoc $\mathrm{z}$,nynějších neřestí vlasti naší milé"،.27

Jan Havlík z Varvažova dedikoval publikaci Albrechtu Janovi Smiřickému (1594-1618). ${ }^{28}$ Dedikantem se tedy stal tehdejší nejbohatší šlechtic v zemi, jenž patřil mezi muže, kteří naplánovali defenestraci v květnu roku 1618. Vyhození místodržících z oken se tento trriadvacetiletý mladík sám aktivně účastnil a poté se za panský stav stal jedním z členů direktoria, které prredstavovalo novou zemskou vládu. Smiřický byl dokonce považován za možného kandidáta na český královský trůn. Vyhlídky na budoucnost v čele království však byly zmařeny jeho smrtí 18. listopadu roku 1618. Bylo to pouhých 17 dní po datování předmluvy představované knihy, takže je vysoce pravděpodobné, že Albrecht Jan Smiřický Discurs o běhu válečném nikdy neviděl.

Jan Havlík v předmluvě vyzdvihuje dedikantovy kladné vlastnosti, mezi kterými jsou jmenovány „,heroitská mysl,

\footnotetext{
${ }^{22}$ Více o něm: TRUHLÁŘ 1966, s. 276-279. Životní data jsou v hesle uvedena chybně, avšak vyplývají z Havlíkova nekrologu zmíněného na s. 277 tamtéž. Nověji k Havlíkovi: HOLÝ 2011, s. 186-187.

${ }^{23}$ Více o něm: TRUHLÁŘ 1966, s. 279.

${ }^{24} \mathrm{~K}$ tehdejšímu politickému a válečnému dění nově např. FUKALA 2018. K vojenským akcím roku 1618 konkrétně s. 41-46.

${ }^{25}$ SCHWENDI 1618, s. [5].

${ }^{26}$ Tamtéž, s. [7].

${ }^{27}$ Tamtéž, s. [8].

${ }^{28}$ Více o něm nově ČECHURA - KUCROVÁ - VLASÁKOVÁ 2018. O Albrechtu Janovi především s. 138-148, 184-186.
} 


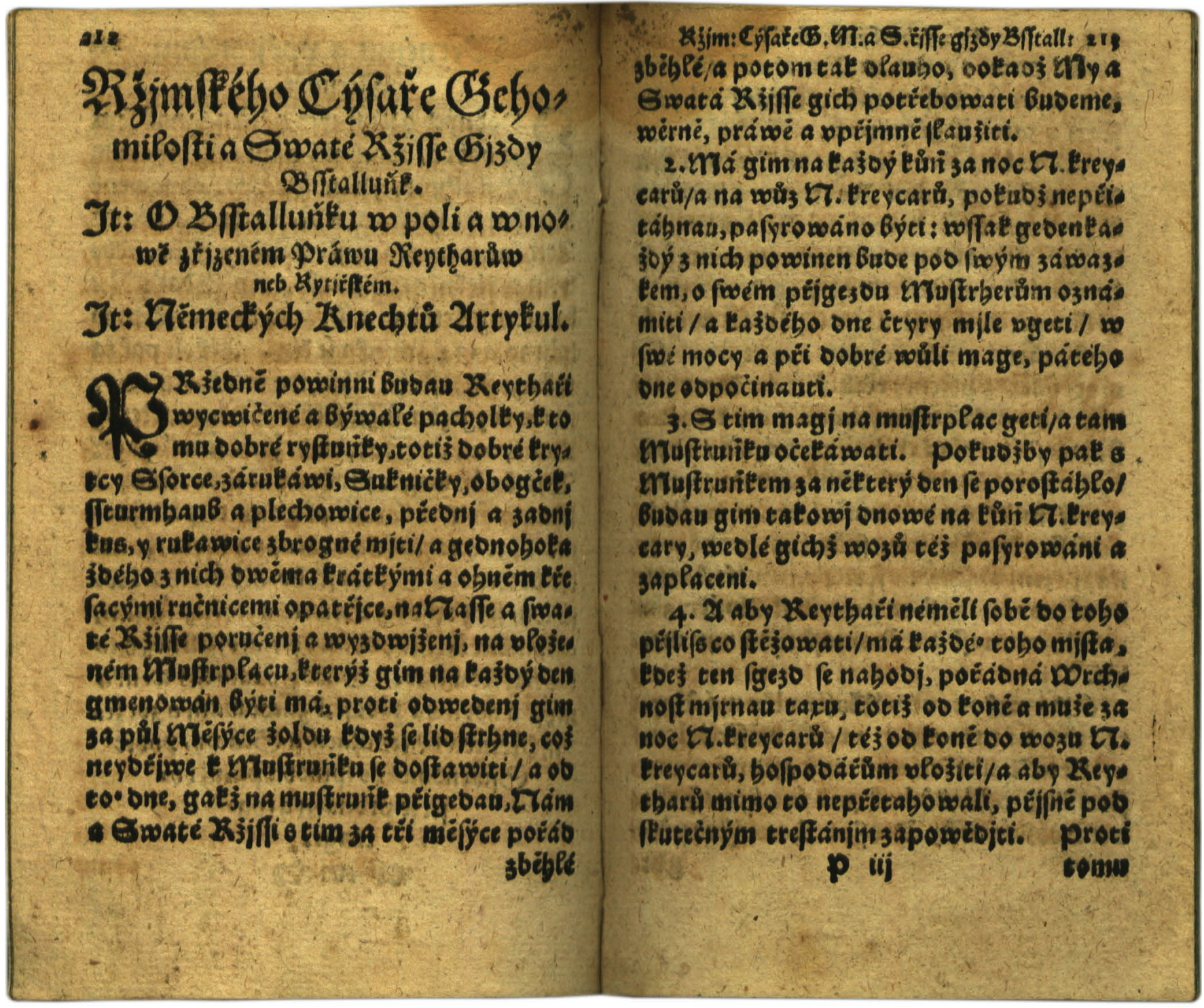

Obr. 4. Za text Schwendiho Discursu je zařazen vojenský řád Maxmiliána II. z roku 1570. Praha, Knihovna Národního muzea, oddělení rukopisů a starých tisků, sign. 30 D 7. Foto: KNM.

k vlasti náchylnost a v zastávání evangelium Kristova horlivost, též v těchto nynějších těžkých časích znamenitá, neustálá a platná práce““. ${ }^{29}$ Snad jsou tím míněny Albrechtovy aktivity $\mathrm{v}$ rámci direktoria $\mathrm{i}$ jeho vojenská podpora stavovské politiky - nemůžeme však říci, že by se Jan Havlík vyjadřoval konkrétně.

V př́ibuzenstvu Jana Havlíka z Varvažova najdeme několik vazeb na rod Smiřických. Víme, že otec Jana Havlíka, Bartoloměj, byl jedním z vychovatelů Václava Smiřického (1554-1593), který ho mj. doprovázel na kavalírské cestě. ${ }^{30} \mathrm{~S}$ Albrechtem Janem Smiřickým měl ovšem bližší vztah nevlastní otec Jana Havlíka, Tobiáš Štefek z Koloděj († 1621). ${ }^{31}$ Tobiáś byl nejprve Albrechtovým preceptorem, poté se stal úředníkem a roku 1614 regentem všech smiřických panství. Kromě toho byl pražským měš'anem a za stavovského povstání působil jako člen direktoria za městský stav. Kvůli svým aktivitám v době rebelie byl roku 1621 popraven na Staroměstském náměstí spolu s dalšími šestadvaceti muži. Jan Havlík v předmluvě Discursu o běhu válečném zmiňuje svou osobní vazbu na Albrechta Jana Smiřického, když tvrdí: „Prostředkováním pana Tobiáše Štefka z Koloděj, mého zvláště milého pana otčíma, nemalé od Vaší Milosti lásky jsem došel.“

Vzhledem $\mathrm{k}$ rodinné vazbě mezi devatenáctiletým Janem Havlíkem a jeho „zvláště milým“ otčímem Tobiášem Štefkem, jedním z členů direktoria, je tedy prakticky nemožné, aby Jan Havlík nebyl alespoň rámcově obeznámen s politickými a vojenskými akcemi, ke kterým roku 1618 docházelo v Českém království. Je proto poměrně pravděpodobné, že Discurs o běhu válečném vyšel právě v této době s dedikací Smiřickému jako jistá podpora myšlenek stavovského povstání a vojenských akcí jeho představitelů.

\footnotetext{
${ }^{29}$ SCHWENDI 1618, s. [7].

30 ČECHURA - KUCROVÁ - VLASÁKOVÁ 2018, s. 182.

${ }^{31}$ O něm např. tamtéž, s. 187; HOLÝ 2011, s. 305-306; TRUHLÁŘ 1982, s. 300-301.
} 


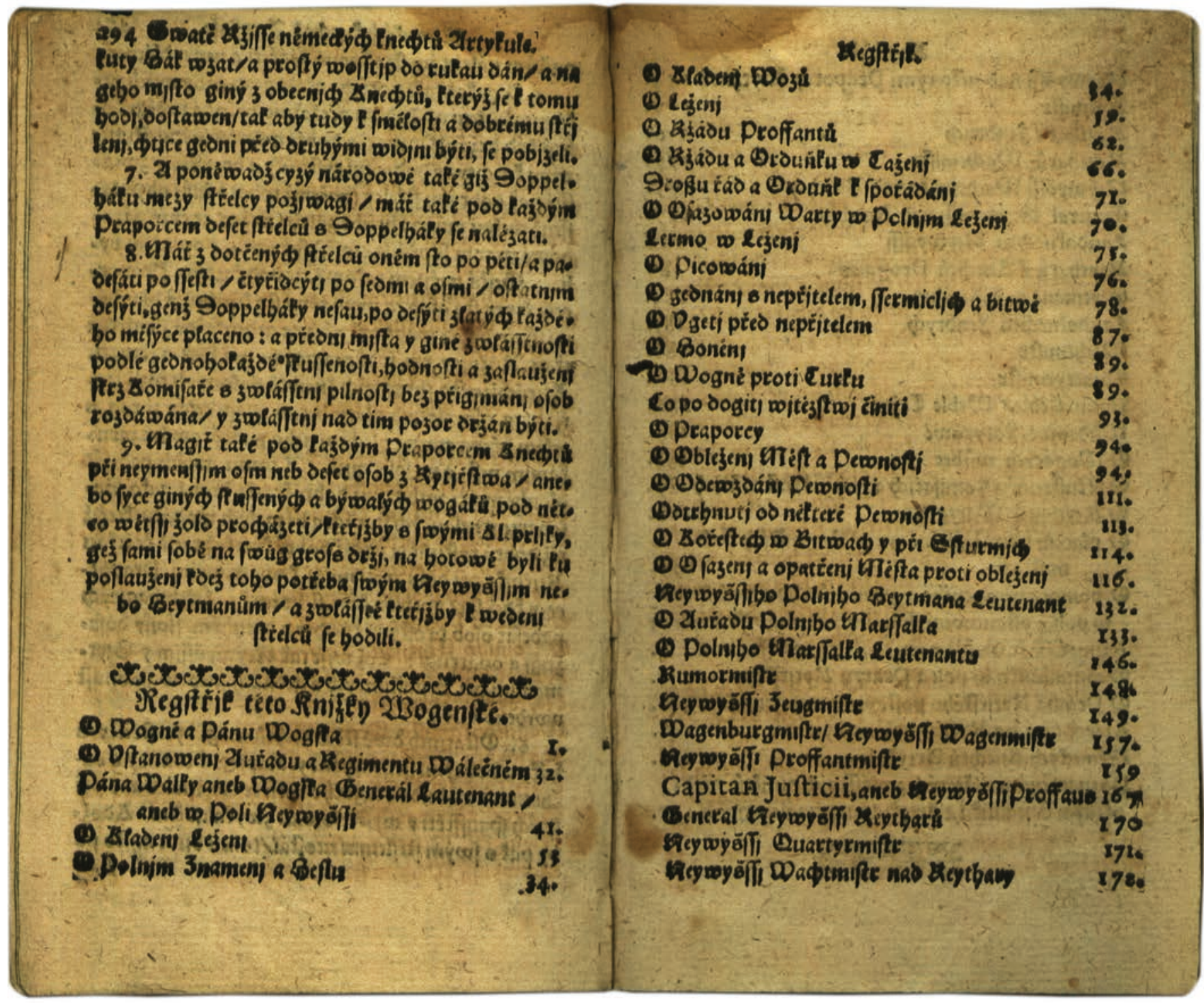

Obr. 5. České vydání bylo po vzoru svého německého předobrazu doplněno přehledem obsahu. Praha, Knihovna Národního muzea, oddělení rukopisů a starých tisků, sign. 30 D 7. Foto: KNM.

\section{Formální aspekty knihy}

Již bylo zmíněno, že český překlad Kriegs Discursu obsahově odpovídá svému německému originálu, a je tomu tak i v otázce členění a typografie textu. Po předmluvě spojené $\mathrm{s}$ dedikací32 následuje hlavní text knihy, který je rozdělen do šedesáti kapitol. Na ně navazuje soupis obsahu, v němž jsou vypsány názvy všech kapitol s odkazy na strany, na nichž příslušné kapitoly začínají. Vyznačovací písmo užité na nadpisy kapitol má o něco větší stupeň než písmo textové. Kapitoly ve všech př́padech navazují na předchozí text pouze s malým odsazením.

Zaměřme se nyní na české vydání. V knize nalezneme pouze občasné využití dekoru. Na první straně předmluvy lze nalézt lištu s motivem vinné révy. Na stránce je též umístěna iniciála $\mathrm{N}$ přes trri řádky. Lišta složená z typografických znamének s rostlinnými motivy je pak natištěna na první straně hlavního textu, kde nalezneme též iniciálu $-\mathrm{v}$ tomto př́pade $\mathrm{D}$ přes čtyři řádky. Iniciály přes tři řádky poté uvozují jednotlivé kapitoly v textu. Na straně 210 je umístěna rozměrná viněta, jejímž cílem bylo zaplnit prázdný prostor na zbytku stránky. ${ }^{33}$ Následující kapitola totiž výjimečně začíná až na dalším listu. Je to proto, že stranou 210 Schwendiho Kriegs Discurs končí a následují texty jiných autorů, o nichž bude řeč později. ${ }^{34}$ Souhrn obsahu knihy odděluje od hlavního textu lišta totožná s tou, která byla natištěna na první stranu hlavního textu. Poslední stránku obsahu uzavírá drobný vlys.

\footnotetext{
${ }^{32}$ Pro zajímavost dodejme, že i dedikace v německých vydáních mají souvislost s našimi dějinami. Německý historik a odborník na tureckou problematiku, který byl editorem německého vydání, Johannes Löwenklau (1541-1594), dedikoval publikaci Karlovi staršímu ze Žerotína (1564-1636), významnému moravskému politikovi, představiteli moravského zemského patriotismu a po dlouhá léta vůdčí osobnosti moravské stavovské obce. Totožná dedikace byla použita ve vydáních z let 1593, 1594 i 1605. Zmíněná dedikace byla jako jediná vypuštěna z českého překladu knihy a nahrazena dedikací Jana Havlíka z Varvažova Albrechtu Janovi Smiřickému.

${ }^{33}$ O horroru vacui více viz VOIT 2008, s. 371-372.

${ }^{34}$ Informace o nich jsou uvedeny v kapitole Obsah knihy.
} 
Německé vydání z roku 1593 bylo vytištěno v kvartovém formátu, vydání z let 1594 a 1605 v osmerkovém. Všechna tři vydání byla realizována $\mathrm{v}$ dílně Claudeho de Marne a Johanna de Aubryho, resp. v případě posledního vydání u dědiců Johanna Aubryho. Jedinou ilustrací byla v německých knihách celostránková podobizna autora publikace. Česká varianta díla byla vytištěna v osmerkovém formátu v dílně Daniela Carolida s Karlsperka. Kniha neobsahovala portrét Lazara von Schwendiho, ale dřevořez erbu rodu Smiřrických, jejichž členu byla kniha dedikována. ${ }^{35}$

Tiskař českého Discursu o běhu válečném Daniel Carolides z Karlsperka (zemř. po 1631) působil v Praze samostatně v letech 1612-1622. Jakožto nekatolík byl po porážce stavovského povstání potrestán peněžitou pokutou a vzhledem k tomu, že odmítl konvertovat ke katolicismu, byl roku 1628 vypovězen a emigroval do Saska. Jeho tiskárna se silně angažovala pro potřby českého stavovského povstání. Carolides vytiskl Druhou apologii stavưv Království českého, ${ }^{36}$ německou verzi České konfese určenou pro cizinu Confessio Bohemica ${ }^{37}$ a řadu dalších tisků podporujících myšlenky povstání. ${ }^{38}$

\section{Obsah knihy}

Discurs o běhu válečném (a stejně tak i jeho německé předchůdce) lze zařadit do kategorie správních vojenských příruček. Zatímco mladší príručky se většinou primárně zaměrovaly na vojenství jako umění (ars militaris) a rozebíraly taktiky, strategie a výcvik vojáků, jádrem tohoto staršího typu publikací byla jiná témata - správní příručky charakterizovaly práva a povinnosti jednotlivých členů vojska a zabývaly se organizací armády na pochodu, ve vojenském táboře nebo při bojových akcích.

Představovaná príručka se na samotném začátku zabývá problematikou války a osobou velitele armády - ,„pána vojska“. ${ }^{39}$ Kapitola je pojata velice ze široka, rozebírá morální a náboženské aspekty války a s rozsahem 32 stran je v rámci příslušné publikace nebývale dlouhá. Tím se výrazně liší od většiny dalších kapitol, jejichž zaměření je již poměrně utilitární a které se rozkládají většinou na jedné až pěti stranách. Rozsah kapitoly i její úvahový charakter lze snadno vysvětlit tím, že jejím autorem byl též velitel armády, který jistě předpokládal, že i čtenáři jeho knihy budou veliteli vojsk, či mladí aspiranti na tuto pozici z řad příslušníků šlechty.
Další dvě kapitoly s tou první úzce souvisí a navazují na ni. ${ }^{40}$ Nejprve je zařazen text $O$ ustanovení our̆adu a regimentu válečném, v němž se čtenář blíže seznámí s právy, povinnostmi a správným působením velitele vojska. Následuje kapitola o generál lajtnantovi, tedy zástupci vojevůdce, který velí armádě, pokud vrchní velitel není přítomen. Značná část tohoto textu pojednává o výběru generál lajtnanta, takže je zjevné, že i tato pasáž byla určena především očím vrchního velitele armády.

Za tímto obšírným úvodem o nejvyšším velení vojska nalezneme jednadvacet kapitol kratšího rozsahu o organizaci vojska v různých situacích. Několik kapitol se zabývá problematikou vojenských táborů. ${ }^{41}$ Setkáme se zde s texty o stavbě tábora, o zř́zení vozové hradby, o zajištění hlídek, o heslech potřebných pro vstup do zabezpečeného tábora, o rozdělení jednotlivých ležení uvnitř něj, o zásobování a proviantu či o vyhlašování poplachu.

Další kapitoly jsou zaměřeny na válečné akce. ${ }^{42}$ Jako první je zde zařazen text o vyjednávání s protivníkem. Následující pasáže se zabývají jak ústupem před nepřítelem, tak jeho pronásledováním po vyhrané bitvě. Samostatná kapitola je zaměřena na specifika války proti Turkům a je pochopitelně ovlivněna Schwendiho osobními zkušenostmi z uherského bojiště. ${ }^{43}$ Kapitola Co po dojití vítězství činiti pak nepojednává o strategických akcích, jak by se snad dalo čekat, ale zmiňuje nutnost děkování Bohu za předešlý úspěch a potřebu pohřbít padlé a vzdát jim čest. ${ }^{44}$

Následující soubor kapitol řeší problematiku obléhání měst a pevností a naopak též jejich zaopatření proti neprríteli. ${ }^{45}$ Do této části knihy je zařazen také text $O$ kořestech v bitvách i př́ šturmích, v němž je pojednáno o specifických nárocích různých osob u vojska na podíl z kořisti. ${ }^{46}$

Práva a povinnosti jednotlivých důstojníků, úředníků i prostých vojáků řeší několik dalších kapitol. ${ }^{47}$ Jednotlivé texty zjevně vycházejí z praxe, jelikož pojednávají mj. o obvyklých problémech, které u nositelů prríslušných hodností a úřadů v armádách zpravidla vyvstávají. Dále je zařazena kapitola o mustruňku, tedy přehlídce jednotky, na níž se kontrolují počty vojáků a jejich vybavení; za ní lze nalézt text o placení žoldu. ${ }^{48}$ Závěrečná kapitola se zabývá péčí o nemocné a zraněné členy armády. ${ }^{49}$

Na tomto místě končí Schwendiho Kriegs Discurs, ale kniha pokračuje. Texty, které jsou zařazeny dále, nepřipojili Bartoloměj ani Jan Havlík, ale již editor německého originálu Johannes Löwenklau. Ačkoliv z české verze jeho

\footnotetext{
35 Srov. SCHWENDI 1618, s. [2].

${ }^{36}$ Druhá Apologie 1619.

${ }^{37}$ CONFESSIO BOHEMICA 1619.

${ }^{38}$ VOIT 2008, s. 149-150.

${ }^{39}$ SCHWENDI 1618 s. 1-32.

40 Tamtéž, s. 32-53.

41 Tamtéž, s. 53-77.

42 Tamtéž, s. 78-89.

43 Tamtéž, s. 89-93.

44 Tamtéž, s. 93-94.

45 Tamtéž, s. 94-132.

${ }^{46}$ Tamtéž, s. 114-116.

47 Tamtéž, s. 132-189.

48 Tamtéž, s. 189-203.

49 Tamtéž, s. 203-210.
} 
zásah není patrný, protože z překladu vypadl jeho podpis za předmluvou $\mathrm{k}$ následujícím pasážím, německá verze tento fakt jednoznačně osvětluje. ${ }^{50} \mathrm{Za}$ Schwendiho vojenským pojednáním je zařazena nejprve předmluva od Johannese Löwenklaua $^{51}$ a poté vojenské ř́dy pro jezdectvo a pro pěchotu od císaře Maxmiliána II. Habsburského (1527-1576) pocházející z roku $1570 .^{52}$

\section{Závěrem}

Do dnešních dnů se nám dochovaly tři známé exempláře představované publikace. ${ }^{53}$ Jeden $\mathrm{z}$ nich je uložen v Národní knihovně ČR,${ }^{54}$ druhý v Knihovně Národního muzea ${ }^{55}$ a třetí ve Strahovské knihovně. ${ }^{56}$ První dva zmíněné tisky byly digitalizovány a jejich elektronické kopie jsou veřejně př́stupné. ${ }^{57}$

Jak velký byl tehdejší náklad knihy, ani zda šla publikace na odbyt, dnes nevíme. Ačkoliv poučky, které spis prezentoval, byly v době vydání českého Discursu již několik desetiletí staré, řada z nich byla stále ještě aplikovatelná v rámci dobového vojenství. Jak bylo výše zmíněno, spis se příliš nezabýval taktikami a strategiemi, ale spíše organizací vojska a jednotlivými úřady a hodnostmi v armádě - a na tom se mnohé do počátku třicetileté války nezměnilo.

Přestože snad bylo záměrem původců knihy podpořit touto publikací stavovské povstání a oslovit jednu z jeho z čelných osobností - Albrechta Jana Smiřického - nemáme zprávy o tom, že by dílo získalo mezi českou (vojenskou) veřejností větší ohlas. Bylo tomu tak snad proto, že potencionálními zájemci o knihu tohoto typu byli především vzdělaní šlechtici a zámožnější měšt’ané, kteří si mohli odpovídající publikace v německém (či jiném cizím) jazyce snadno pořídit např. nákupem na knižních veletrzích ve Frankfurtu nad Mohanem a v Lipsku. Nabídka německých, francouzských nebo italských vojenských prríruček v roce 1618 byla podstatně širší než nabídka česká zahrnující pouze jedinou knihu daného žánru.

\section{Prameny:}

ACHILlES 1595: ACHILlES, Jan. Knjžka o Polnjm Hegtmanu, a giných Spráwcých Wogenských. Praha: [nakladatel není známý], 1595. K00092.

BARTOLOMEUS 1619: BARTOLOMEUS, Jiří. Kázanj krátké, ku potěssenj a napomenutj pobožným Wogákům. Hradec Králové: Martin Klenwechter, [1619?]. K00977.

CONFESSIO BOHEMICA 1619: CONFESSIO BOHEMICA, Hoc est CONFESSIO SANCTAE ET
CHRISTIANAE FIDEI, OMNIUM TRIUM ORDINUM REGNI BOhemiae. Praha: Daniel Carolides z Karlsperka, 1619. BCBT39370.

Druhá Apologie 1619: Druhá Apologie Stawưw Králowstwj Českého, Tělo a Krew Pána Gežisse Krysta pod Obogj přigjmagjcých. Praha: Daniel Carolides z Karlsperka, 1619. K00235.

HOŠEK 1799: HOŠEK, Jan. Přednosti Stawu Wogenského. Praha: Jan Beránek, 1799. K03189.

KHEWENHÜLLER 1733: KHEWENHÜLLER, Ludwig Andreas von. Prawidlo Wogenského Ržjzeni, Které Gá Hrabě KHEVENHILLER, Mému od Geho Cýsařské Milosti Neymilostiwěgic swěrenému Dragonůw Regimentu, s tim predpisugj, a odewssech bedliwě zachowati žádám. Brno: Jakub Maxmilián Svoboda, 1733. K14346.

KONIÁŠ 1770: KONIÁŠ, Antonín. Index Bohemicorum librorum prohibitorum, et corrigendorum ordine alphabeti digestus. Praha: Jan Karel Hraba, 1770. K04298.

SCHWENDI, Lazarus von. Ein kurzer Begriff von den Kriegsämptern. Österreichischen Nationalbibliothek, sign. Cod. 10893 HAN MAG.

SCHWENDI 1593: SCHWENDI, Lazarus von. Kriegs Discurs. Frankfurt am Main: Claude de Marne und Johann Aubry, 1593. VD16 S 5074.

SCHWENDI 1594: SCHWENDI, Lazarus von. Kriegs Discurs. Frankfurt am Main: Claude de Marne und Johann Aubry, 1594. VD16 S 5075.

SCHWENDI 1605: SCHWENDI, Lazarus von. Kriegs Discurs. Frankfurt am Main: Claude de Marne und Johann Aubry Erben, 1605. VD17 547:630070A.

SCHWENDI 1618: SCHWENDI, Lazarus von. Discurs o Běhu Wálečném a Auřadech Wogenských. Praha: Daniel Carolides z Karlsperka, 1618. K15404.

SCHWENDI 1676: SCHWENDI, Lazarus von. Herrn Lazari von Schwendi, Freyherrn zu HohenLandsberg \&c. ... Kriegs Discurs. [Görlitz]: Hübner; Dresden: Bergen, 1676. VD17 39:120504Y.

ZLOBICKÝ 1798: ZLOBICKÝ, Josef Valentin. [Článkowé wojenští pro c. $k$. armádu]. Vídeň: [nakladatel není známý], 1798. K01789.

\section{Literatura:}

ANDRESOVÁ 2015: ANDRESOVÁ, Klára. Vojenské právo za třicetileté války na př́kladu vojenských řádů Maxmiliána II. a Gustava II. Adolfa. In: Bibliotheca Antiqua 2015. Olomouc: Vědecká knihovna v Olomouci, 2015, s. 140-145.

\footnotetext{
${ }^{50}$ Srov. tamtéž, s. 211, kde lze za textem nalézt pouze dvě ukazovací ručičky a dvě hvězdičky na spodu stránky; a SCHWENDI 1593, s. 118, kde za textem nalezneme podpis „H. Lewenklaw V. A.“. Stejný podpis se nachází u totožných pasáží i ve vydání 1594 na s. 222 a ve vydání 1605 na s. 222.

${ }^{51}$ SCHWENDI 1618, s. 211.

${ }^{52}$ Tamtéž, s. 212-294. Vojenské řády Maxmiliána II. byly vydávány tiskem ještě ve 30. a 40. letech 17 . století - je tedy zjevné, že tyto normativní publikace z roku 1570 měly jistou relevanci v průběhu celé třicetileté války. Více k Maxmiliánovu řádu a jeho mladším vydáním ANDRESOVÁ 2015, s. 140-145.

${ }^{53}$ Viz Knihopis, K15404 - online dostupné: https://aleph.nkp.cz/F/?func=direct\&doc number=000015453\&local base $=$ KPS [cit. 15. 7. 2019].

${ }^{54}$ Sign. 54 E 118. Tisk není kompletní, chybí mu dvě poslední strany; záznam v katalogu NK ČR však chybně uvádí, že se jedná o dva poslední listy. Srov. https://aleph.nkp.cz/F/?func $=$ direct\&doc number $=000055885 \&$ local base $=$ STT [cit. 15. 7. 2019].

${ }^{55}$ Sign. 30 D 7.

${ }^{56}$ Sign. AA XV 51

${ }^{57}$ Exemplář z Národní knihovny ČR: http://www.manuscriptorium.com/apps/index.php?direct=record\&pid=NKPEOD-NKCR_54_E_000118_1Q3FA78-cs [cit. 15. 7. 2019]; exempláŕ z Knihovny Národního muzea: https://stt.opac.nm.cz/documents/26802 [cit. 15. 7. 2019 ].
} 
ANDRESOVÁ 2018: ANDRESOVÁ, Klára. Vojenské příručky raného novověku jako předmět výzkumu historiografie vojenství a knihovědy: tisky středovýchodní Evropy v kontextu evropské produkce. Vojenská história 22, 2018, č. 3, s. 61-80.

ANDRESOVÁ 2019: ANDRESOVÁ, Klára. Military Camps in Military Manuals. In: Negotiating Conflict and Controversy in the Early Modern Book World. Leiden: Brill, 2019, s. 163-177.

Biografický slovník 2004: Biografický slovník českých zemí. A. Praha: Libri, 2004.

ČECHURA - KUCROVÁ - VLASÁKOVÁ 2018: ČECHURA, Jaroslav - KUCROVÁ, Veronika VLASÁKOVÁ, Zuzana. Smiřičti: krátké dějiny úspěšného rodu. Praha: Nakladatelství Lidové noviny, 2018.

FUKALA 2018: FUKALA, Radek. Třicetiletá válka 1618-1648. I. dill, Pod vitězným praporem habsburské moci (1618-1629). České Budějovice: Veduta, 2018.

HOLÝ 2010: HOLÝ, Martin. Zrození renesančního kavalíra: výchova a vzdélávání šlechty z českých zemí na prahu novověku (1500-1620). Praha: Historický ústav, 2010.

HOLÝ 2011: HOLÝ, Martin. Ve službách šlechty: vychovatelé nobility z českých zemí (1500-1620). Praha: Historický ústav, 2011.

CHOTEK Z CHOTKOVA 1895: CHOTEK Z CHOTKOVA, Zikmund. Zpráva a naučení kratičké strany věci vojanské. In: DVORSKÝ, Ferdinand (ed.). Sněmy české 1592-1594. Praha: Nákladem Výboru zemského Království českého, 1895, s. 415-442. Dostupné též online: http://www. psp.cz/eknih/snemy/v080/1593-94/t015601.htm [cit. 8. 7. 2019].

JANOVSKÝ 1993: JANOVSKÝ, Miroslav. Z historie knihovny Vojenského historického ústavu. Historie a vojenstvi 41, 1993, č. 2, s. 111-125.

JÄHNS 1890: JÄHNS, Max. Geschichte der Kriegswissenschaften vornehmlich in Deutschland: Zweite Abteilung, XVII. und XVIII. Jahrhundert bis zum Auftreten Friedrichs des Großen 1740. München und Leipzig: R. Oldenbourg, 1890.

JUNGMANN 1849: JUNGMANN, Josef. Historie literatury české, aneb saustawný přehled spisů českých s krátkau historii národu, oswícení a jazyka. V Praze: Nákladem Českého museum, 1849.

KÖNIG 1934: KÖNIG, Johann. Lazarus von Schwendi Röm. Kaiserl. Majestät Rat und Feldoberst 1522-1583: Beitrag zur Geschichte der Gegenreformation. Schwendi: Georg Schmid, 1934.

NICKLAS 1995: NICKLAS, Thomas. Um Macht und Einheit des Reiches: Konzeption und Wirklichkeit der Politik bei Lazarus von Schwendi (1522-1583). Husum: Matthiesen Verlag, 1995.

OPAVOVÁ 2013: OPAVOVÁ, Tereza. Obraz války a vojenství v 16. a 17. století očima českých šlechticů. Praha 2013. Diplomová práce. Univerzita Karlova v Praze. Filozofická fakulta.

PICKOVÁ 1965: PICKOVÁ, Věra. Císařské vojsko v Uhrách v 16. století očima současníků. Historie a vojenství 13, 1965, č. 5, s. 789-799.

ŠŤOVÍČEK 2002: ŠŤOVÍČEK, Ivan. Zásady vydávání novověkých historických pramenů z období od počátku 16. století do současnosti: př́prava vědeckých edic dokumenti̊ ze 16.-20. století pro potřeby historiografie. Praha: Archivní správa Ministerstva vnitra ČR, 2002.

TRUHLÁř et al 1966: TRUHLÁř, Antonín et al. (edd.). Rukovět' humanistického básnictví v Čechách a na Moravě: Enchiridion renatae poesis Latinae in Bohemia et Moravia cultae. $\check{C}-J$. Praha: Nakladatelství Československé akademie věd, 1966.

TRUHLÁř at al. 1982: TRUHLÁŘ, Antonín et al. (edd.). Rukovět' humanistického básnictví v Čechách a na Moravě: Enchiridion renatae poesis Latinae in Bohemia et Moravia cultae. S-Ž., 1982.

VOIT 2008: VOIT, Petr. Encyklopedie knihy: starši knihtisk a príbuzné obory mezi polovinou 15. a počátkem 19. století. Praha: Libri, 2008.
Klára Andresová
Historický ústav AV ČR
oddělení biografických studií
Prosecká 809/76
19000 Praha 9 - Prosek 